\title{
A Phenotypic Characterization of Rarámuri Criollo Cattle Introduced into the Southwestern United States ${ }^{1}$
}

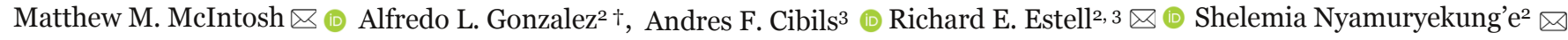

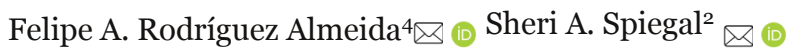 \\ Department of Animal and Range Sciences, New Mexico State University, USA
}

\begin{abstract}
Our objective was to describe key phenotypic characteristics of a population of Rarámuri Criollo (RC) cattle introduced from the Copper Canyon of Chihuahua, México into the Southwestern United States almost two decades ago. We recorded 26 phenotypic traits of $37 \mathrm{RC}$ individuals including mature cows, first-calf heifers, and mature bulls raised at the USDA-ARS Jornada Experimental Range in southern New Mexico. This herd of RC cattle exhibited intermediate body sizes (390 kg) compared to the smaller Corriente (300 kg) and larger Texas Longhorn $(400 \mathrm{~kg}$ ) and Florida Cracker cattle $(400 \mathrm{~kg}$ ). Coat colors were similar to those described for other Criollo biotypes but horn shape and size of RC appear to be different than that of other US-based Criollo breeds. Though smaller than commercial beef breeds, RC cattle appear to be well-matched to the Southwestern US environments as evidenced by previous studies that evaluated their grazing behavior, weight gains, and carcass quality. Rarámuri Criollo cattle are a genetic resource whose conservation could be critically important for climate change adaptation of ranches in the desert Southwest.
\end{abstract}

Keywords: heritage breed, genetic conservation, beef cattle, climate change

\section{Una caracterización fenotípica del ganado Criollo Rarámuri introducido en el suroeste de los Estados Unidos}

Resumen. El objetivo de este trabajo fue describir las características fenotípicas de una población de ganado bovino Criollo Rarámuri (CR) introducido desde las Barrancas del Cobre en Chihuahua, México al Sudoeste de los Estados Unidos hace aproximadamente dos décadas. Se registraron 26 características fenotípicas en 37 individuos Criollo Rarámuri incluidos vacas adultas, vaquillonas de primer parto y toros adultos criados en el campo experimental La Jornada del Servicio de Investigaciones Agropecuarias del Departamento de Agricultura de los Estados Unidos ubicado en el sur del estado de Nuevo México. El rodeo de Criollo Rarámuri evaluado presenta tamaños corporales intermedios entre el ganado bovino Corriente (más liviano) y el Texas Longhorn y Florida Cracker (más pesados). El CR presenta colores de pelaje similares a los descriptos para otros biotipos de ganado bovino Criollo, pero el tamaño y la forma de la cornamenta del Criollo Rarámuri son diferentes de otras razas Criollas de los EE.UU. Aunque el tamaño del CR es menor que el de bovinos de razas carniceras mejoradas, este ganado aparenta estar mejor adaptado al ambiente árido del SO de los Estados Unidos como sugieren los resultados de ensayos experimentales previos que evaluaron su conducta de pastoreo, su ganancia de peso, y calidad de carne. El CR es un recurso genético cuya conservación podría ser sumamente importante como herramienta de adaptación al cambio climático y sus efectos sobre la ganadería extensiva en el SO de los EE.UU.

Palabras clave: raza ancestral, conservación genética, bovinos de carne, cambio climático

\footnotetext{
Received: 2020-10-14. Acepted: 2020-11-06.

${ }^{1}$ This research was a contribution from the Long-Term Agroecosystem Research (LTAR) Food and Agriculture, Hatch project 1000985 (A. Cibils) and SAS CAP grant \# 1912726269.

† Deceased.

${ }^{2}$ United States Department of Agriculture-Agriculture Research Service, Jornada Experimental Range, USA.

3Corresponding authors: acibils@nmsu.edu and rick.estell@usda.gov

4Facultad de Zootecnia y Ecología, Universidad Autónoma de Chihuahua, México.
}

network. LTAR 17 is supported by the United States Department of Agriculture. Partial support was provided by the USDA National Institute of 


\section{Introduction}

Loss of adaptive traits present in many ancestral livestock heritage breeds is occurring at an accelerated rate (Long, 2008). Heritage (also: "adapted", "rare", "legacy", or "traditional") livestock are primarily found in developing nations (70 \%), and a 2007 report by the United Nations Food and Agriculture Organization (FAO, 2007) found that Europe and the United States are at the greatest risk globally for loss of breed diversity (Long, 2008). Conservation of heritage livestock breeds is important for preserving genetic diversity (Long, 2008) which is critical to ensuring adaptation to global climate change. The use of heritage cattle genetics to meet animal production and ecosystem conservation goals on grazing lands has gained momentum in the recent past (Rook et al., 2004; Scasta, Lalman, \& Henderson, 2016; Pauler et al., 2019). Heritage livestock tend to be smaller than commercial livestock breeds, hence they require less energy, can yield larger calf crop totals (through longevity, increased livestock numbers, and more pounds of weaned beef), are better able to adapt to climate and weather variation (Scasta et al., 2016), and exhibit foraging behaviors that have been associated with lower environmental footprints when compared to conventional beef cattle breeds (Allred et al., 2011; Anderson et al., 2015; Pauler et al., 2019; Peinetti et al., 2011).

Criollo cattle are descendants of Iberian cattle brought to the Americas by early European explorers (Anderson et al., 2015). There are 33 known Criollo biotypes throughout the Americas today (De Alba Martinez, 2011). A small herd of Rarámuri Criollo (RC), a biotype from the southern portion of the Copper Canyon in México, was introduced into southern New Mexico, USA, in 2005 (Anderson et al., 2015; Figure 1).
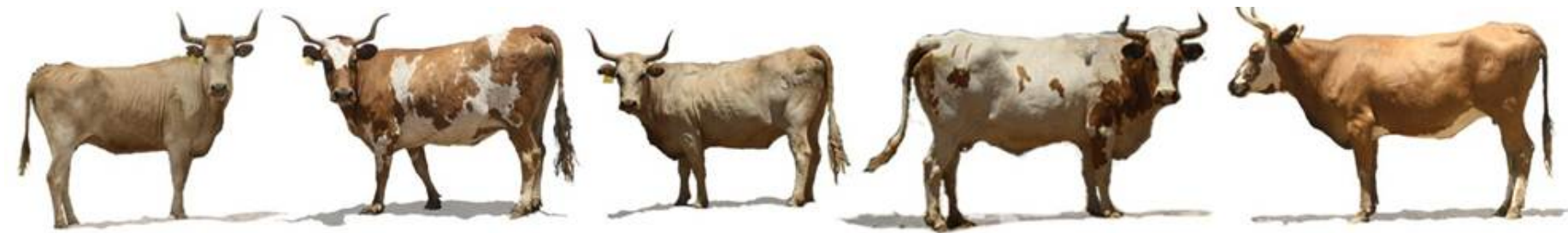

Figure 1. Representative photographs of five mature Rarámuri Criollo cows measured for this study.

Since then, some studies have compared its grazing behavior to that of Angus $\times$ Hereford cattle $(\mathrm{AH}$; a commercial crossbreed common throughout the US) in the Chihuahuan Desert (Nyamuryekung'e, 2020; Peinetti et al., 2011; Spiegal et al., 2019). These studies consistently showed that, compared to their British crossbred counterparts, RC cows explored larger areas of extensive desert range and traveled further during times of the year when forages are dormant and when vegetation and soils are most vulnerable to degradation. Researchers have therefore speculated that raising Criollo cattle may allow desert ranchers to meet animal production and rangeland conservation goals in the US southwest where the climate is becoming hotter and drier (Polley et al., 2013; Havstad et al., 2018; Spiegal et al., 2020). Rusticity traits present in Rarámuri Criollo cattle are thought to be the result of four centuries of semi-natural selection (Anderson et al., 2015). Preserving this valuable livestock resource hinges on a detailed description of its phenotypic and genotypic characteristics. Although several studies have characterized genotypes of Criollo cattle from Chihuahua, México (Russell et al., 2000;
Ulloa-Arvizu et al., 2008; Ginja et al., 2019), to our knowledge, no systematic description of Rarámuri Criollo phenotypic traits has been published to date. Our phenotypic characterization of this herd of Rarámuri Criollo cattle could provide an initial biotype standard to differentiate it from others currently used in the United States.

In this study, we recorded 26 phenotypic characteristics of a select group of RC cows with correct conformation (see materials and methods for detailed description), heifers, and bulls from the Jornada Experimental Range (JER; USDA-ARS) herd following protocols established by the Asociación de Criadores de Ganado Criollo Mexicano. This characterization is important because it can serve as a basis to inform relationships among phenotypic traits, genotypes, rusticity, and foraging behavior, therefore we sought to 1) identify specific phenotypic characteristics of the JER Rarámuri Criollo herd; and 2) develop an initial biotype standard for selection of $\mathrm{RC}$ cattle. 


\section{Materials and Methods}

This study was approved by the New Mexico State University IACUC. Data were collected at the JER in south-central New Mexico ( $32^{\circ} 37^{\prime} 01^{\prime}$ N, $106^{\circ} 44^{\prime} 30^{\prime \prime}$ W) between June 5 and July 23, 2019. The JER is located in the northern portion of the Chihuahuan Desert where the annual mean temperature is $14.1^{\circ} \mathrm{C}$ with hot summers $\left(29.8{ }^{\circ} \mathrm{C}\right)$ and late summer monsoon rains averaging $228.6 \mathrm{~mm} \cdot \mathrm{y}^{-1}$.

Animals in our study had ad libitum access to water in all pastures and corrals throughout. Animals received no supplemental feed during the study but were given ad libitum access to a mineral block and hay when in corrals and ad libitum access to forage when on pasture. The recommended stocking rate for JER pastures used is 5.14 ha $\cdot$ AUM $^{-1}$ (NRCS, 2017), but pastures used by animals in this study were stocked lightly at approximately $9 \mathrm{ha} \cdot \mathrm{AUM}^{-1}$.

Twenty-eight multiparous mature RC cows $(389.7 \pm$ $22.9 \mathrm{~kg})$, four primiparous RC heifers $(286.9 \pm 16.2$ $\mathrm{kg})$, and five mature RC Bulls $(618.2 \pm 9.8 \mathrm{~kg})$ from our experimental herd were selected for preferred conformation traits (including leg straightness, back straightness, "traditional" horn-set, and femininity [for cows]). Cows and bulls were brought from their pastures to the ranch headquarters corrals on June 5, 2019, July 1, 2019, and July 31, 2019 and held in pens for approximately 2 days so that phenotypic measurements could be recorded.

Cows, heifers, and bulls were weighed using a manual scale at the JER ranch headquarters (Buffalo Scale Co.). Animals were fasted overnight before weighing. Weights were recorded to the closest half kilogram. Cow, heifer, and bull withers heights were measured using a marked ruler (from the ground to the tallest point of the thoracic vertebrae) and recorded to the closest $\mathrm{cm}$ (Figure 2i).

A measuring tape was used to determine: thorax (chest) girth (by measuring the widest part of the animals thorax, directly dorsal to the front radiocarpal joint [elbow], Figure 2p); hip width (by measuring the widest point from each of the animals' tuber coxae [the most lateral point of the ilium], Figure 2a); tibiofemoral joint (caudal stifle) circumference (Figure 20); body length (by measuring from the tallest thoracic vertebrae [withers] to the posterior dorsum [tailhead], Figure 2l); neck length (by measuring from the dorsal occipital protrusion [rear poll] to the tallest thoracic vertebrae [withers], Figure 2n); and tail length (by measuring from the posterior dorsum [tailhead] to the dorsal coccygeal vertebrae [end of tail], Figure 2m). Cows, heifers, and bulls were assigned a backstraightness index (1-5, figure 2j). Horn width (distance between each horn tip [cm], Figure 2d), length (length from base to tip of horn [cm], Figure 2e), and diameter (the widest point of the animals' horn [cm], Figure 2b) were measured on each animal. In each female animal, the gestation trimester was determined by rectal ultrasound, performed by a veterinarian.

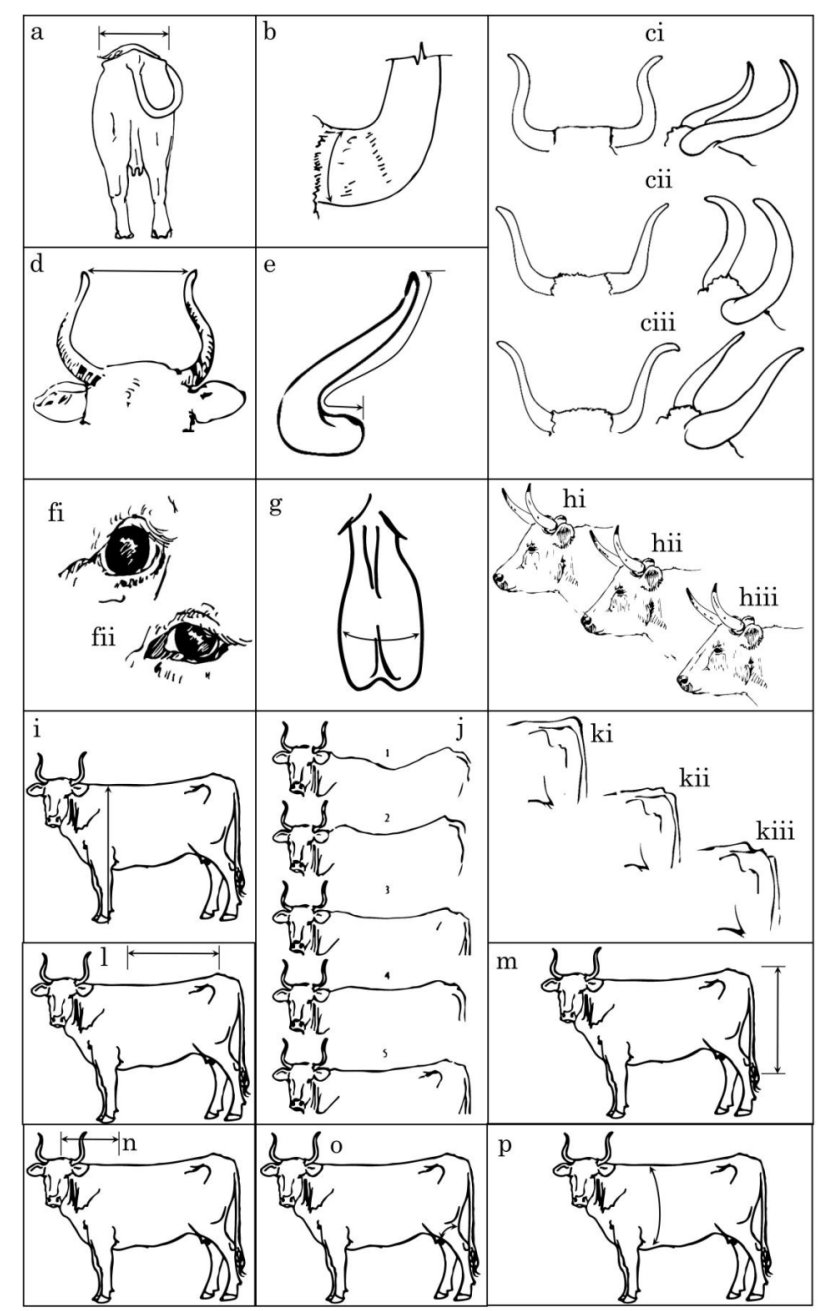

Figure 2. Schematic diagram of phenotypic parameters measured on each Rarámuri Criollo cow, heifer, and bull in our study: (a) hip width, (b) horn diameter, (c) horn classifications: (ci) "lyre," (cii) "open-back," (ciii) "open-front," (d) horn width, (e) horn length, (f) eye shapes: (fi) round, (fii) oblique, (g) scrotal circumference (bulls only), (h) nose-bridge types: (hi) concave, (hii), straight, (hiii) convex, (i) withers height, (j) back straightness conformation (1-5 scale; $1=$ least straight, $5=$ most straight), (k) tail head insertion classifications: (ki) high, (kii) medium, (kiii) low, (l) body length, (m) tail length, (n) neck length, (o) tibiofemoral joint circumference (rear flank), (p) thoracic (chest) girth.

Qualitative traits recorded closely followed the guidelines of the Asociación de Criadores de Ganado Criollo Mexicano (Hernández Sandoval, 2012) and included coat color, muzzle color, nasal ridge (nose) type (Figure 2h), horn set (Figure 2c), nasal ridge pigmentation (nose color), pinna (ear) type (short or 
long), oculus (eye) shape (Figure 2f), palpebral pigmentation (eyelid color; black, beige, or white), posterior dorsum (tail head) set (Figure 2k), hoof color (black or white), hoof consistency (length of hooves; short or long), and hair type (length of hair; short or long).
We used the PROC MEANS procedure in SAS 9.4 (SAS Institute, Cary, NC) to determine the means and standard errors of each quantitative phenotypic trait. Qualitative traits were summarized using MS Excel.

\section{Results and Discussion}

Averages and SE for quantitative phenotypic traits are shown in Table 1. Qualitative traits were analyzed as percentages of the sample JER population and are shown in Figure 3. Coat colors were broadly distributed and were classified among a range of values including $3,8,16,5,14,5,5,5,11,24,3 \%$ for gray, white, black, black and white, blonde, gold, brindle, red-brown, red and white, red, and dark red, respectively. The frequency of coat colors among the sampled population is shown in Figure 4.

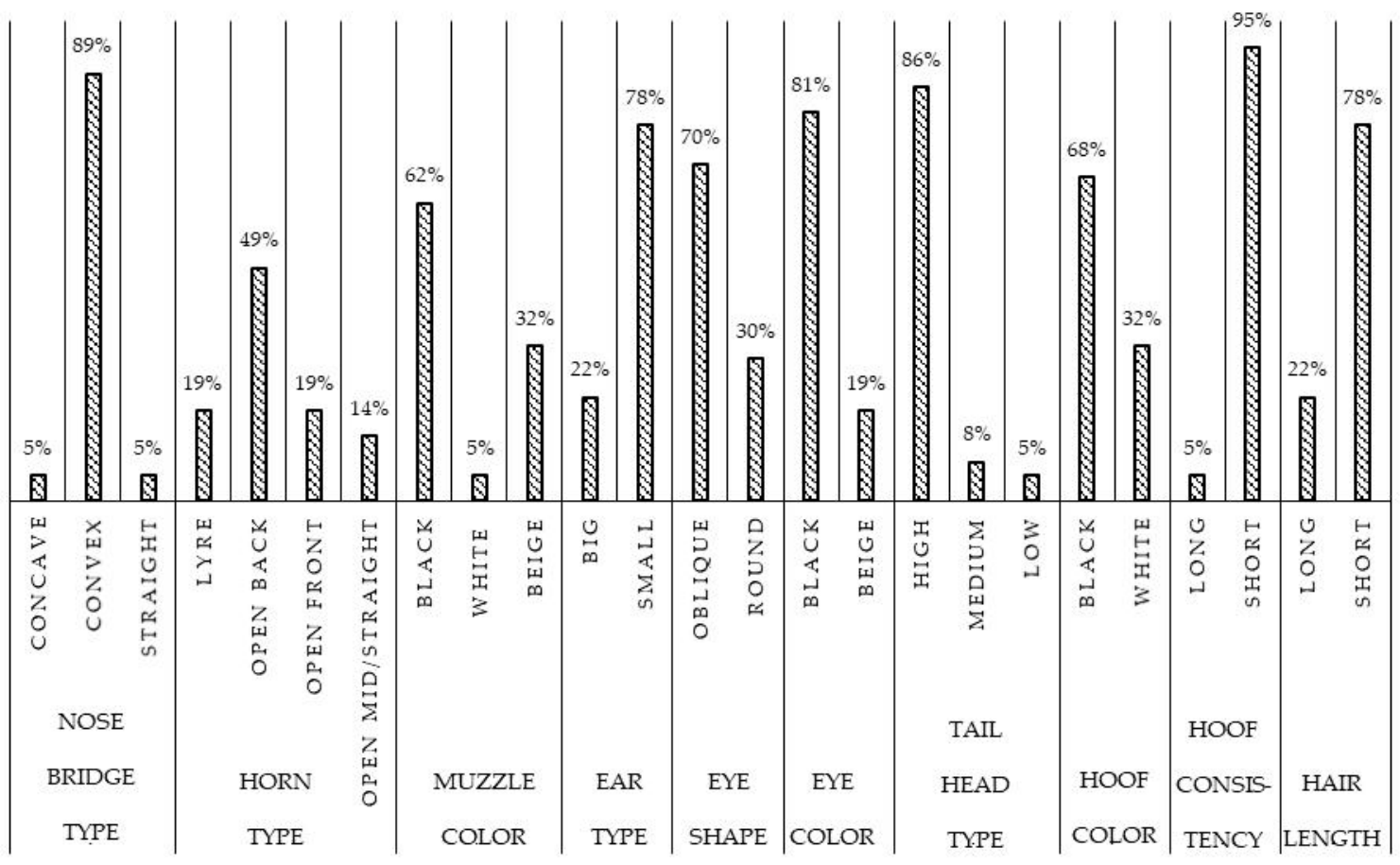

Figure 3. Population percentages of Rarámuri Criollo (all cows, heifers, and bulls) cattle at the USDA ARS Jornada Experimental Range for each qualitative phenotypic trait.

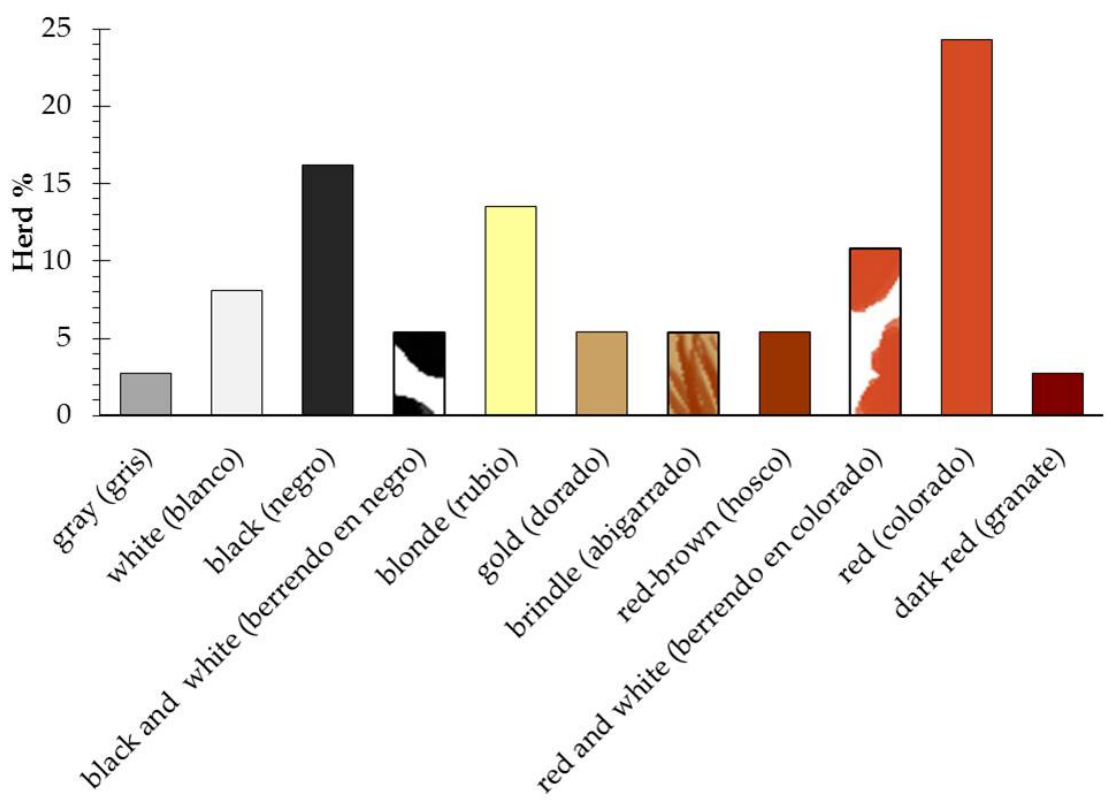

Figure 4. Percentages of Rarámuri Criollo sample population dominant coat color (all cows, heifers, and bulls; $\mathrm{n}=37$ ). 
Our phenotypic characterization of this herd of Rarámuri Criollo cattle could provide an initial biotype standard to differentiate it from others currently used in the United States. This characterization is important because it can serve as a basis to inform relationships among phenotypic traits, genotypes, rusticity, and foraging behavior. For example, we found that $78 \%$ of the JER RC herd could be classified as having short hair suggesting that RC cattle, like other Criollos, may exhibit a dominant inherited trait (SLICK) for short hair (Huson et al., 2014; Pitt et al., 2019) which could make this heritage biotype more heat tolerant than most commercial breeds. Nyamuryekung'e (2020) reported that in summer, $\mathrm{RC}$ cattle had lower body temperature than commercial Angus $\times$ Hereford beef cattle during the hottest hours of the day. They also reported that movement and activity patterns of RC were greatest during hot afternoon hours of summer days.

Rarámuri Criollo cattle in this study exhibited overall body weights that were intermediate (Table 1) compared to the lighter Corriente $(\sim 240-360 \mathrm{~kg}$; NACA, 2010, 2020) and heavier Texas Longhorn $(\sim 300-400 \mathrm{~kg}$; Halloran and Shrader, 1960; Sponenberg and Olson, 1992) or Florida Cracker $(\sim 300-400 \mathrm{~kg}$, Sponenberg and Olson, 1992) breeds/biotypes. Coat colors exhibited by all four breeds/biotypes are generally similar (Sponenberg and Olson, 1992) but horn shape and size appear to differ among RC, Longhorn, and Florida Cracker breeds/biotypes.

Table 1. Means and standard errors of quantitative traits of the USDA-ARS Jornada Experimental Range herd of Rarámuri Criollo cattle.

\begin{tabular}{lcccr}
\hline & $\begin{array}{c}\text { Multiparous } \\
\text { cycling cows } \\
\mathrm{n}=12\end{array}$ & $\begin{array}{c}\text { Multiparous } \\
\text { gravid cows } \\
\mathrm{n}=16\end{array}$ & $\begin{array}{c}\text { Primiparous gravid } \\
\text { heifers } \\
\mathrm{n}=4\end{array}$ & Bulls \\
& $\begin{array}{c}\mathrm{n}=5 \\
\mathrm{n}\end{array}$ & $59.8 \pm 2.3$ & $54.0 \pm 4.7$ & $68.8 \pm 6.0$ \\
\hline Horn width (cm) & $61.0 \pm 2.2$ & $39.6 \pm 1.3$ & $28.5 \pm 1.5$ & $55.0 \pm 2.9$ \\
Horn length (cm) & $40.3 \pm 2.9$ & $181.4 \pm 1.5$ & $157.0 \pm 2.6$ & $208.8 \pm 2.1$ \\
Girth (cm) & $199.4 \pm 2.4$ & $44.4 \pm 0.8$ & $40.0 \pm 0.7$ & $45.6 \pm 1.5$ \\
Hip width (cm) & $44.7 \pm 0.4$ & $120.1 \pm 1.2$ & $116.2 \pm 1.5$ & $132.8 \pm 2.7$ \\
Height (cm) & $124.0 \pm 0.9$ & $4.63 \pm 1.3$ & $4.75 \pm 2.5$ & $4.0 \pm 0.4$ \\
Back conf. (1-5) & $4.67 \pm 1.4$ & $54.3 \pm 1.2$ & $46.3 \pm 1.3$ & $58.8 \pm 2.2$ \\
Flank girth (cm) & $49.3 \pm 0.8$ & $412.6 \pm 9.2$ & $286.9 \pm 16.2$ & $618.2 \pm 9.8$ \\
Body weight (kg) & $366.8 \pm 9.8$ & $91.5 \pm 2.9$ & $73.5 \pm 0.6$ & $97.6 \pm 1.2$ \\
Body length (cm) & $90.0 \pm 1.2$ & $51.8 \pm 1.3$ & $49.3 \pm 0.8$ & $55.0 \pm 1.3$ \\
Neck length (cm) & $52.3 \pm 1.1$ & $84.7 \pm 1.7$ & $81.3 \pm 2.1$ & $91.8 \pm 3.9$ \\
Tail length (cm) & $81.5 \pm 2.5$ & $\mathrm{~N} / \mathrm{A}$ & $\mathrm{N} / \mathrm{A}$ & $36.8 \pm 0.7$ \\
Scrotal circ. (cm) & N/A & & & \\
\hline
\end{tabular}

aultiparous gravid cows were all in the second trimester of pregnancy.

b We could not make inferences about differences among multiparous cycling and gravid cow chest and flank girths due to the small number of animals in this study.

Texas Longhorn cattle exhibit lyrate horns, like RC, but which are typically much larger in diameter and spread. Halloran and Shrader (1960) reported that Texas Longhorn horn widths could range from 97-120 $\mathrm{cm}$ in cows, with greater widths achieved by steers. Florida Cracker cattle appear to exhibit tremendous horn variability from natural polled-ness to widespread, crumpled, or even down-turned horns (Sponenberg and Olson, 1992). Corriente cattle also exhibit the "lyrate" horn shape, but more often tend to exhibit an "open-front" type, as they have been selectively bred for this trait which aids in roping and bull-dogging sporting events (Hawkes, Lillywhite, \& Libbin, 2006; NACA, 2010). The lyrate horn-shape exhibited in US Criollo biotypes is likely influenced by ancestral Spanish and Portuguese breeds like the Maroneza, Rubia, Morucha, Asturian Mountain, and Tudanca, or even ancient Hamitic breeds (Camargo, 1990) but less so from incursions by B. indicus based breeds, as suggested by Ginja et al. (2019) and Pitt et al. (2019) who showed Texas Longhorn and Florida
Cracker cattle only expressed between 3 and 8 percent $B$. indicus influence.

Few detailed phenotype records exist for US-based Criollo types; therefore, future work to record this information could help discriminate biotypes as is common throughout Mexico and parts of Latin America. For instance, the Asociación de Criadores de Ganado Criollo Mexicano provides details of these traits for several Mexican Criollo biotypes (Hernández Sandoval, 2012). In the US, Longhorn breeders who initially sought to conserve and develop the biotype into a breed characterized animals by phenotype and later by blood-typing. Sponenberg et al. (2019) suggested this method was sound because post-hoc blood-typing required only minimal culling of nonLonghorn animals from the base herd.

The group of Rarámuri Criollo in this study, a subbiotype of Chihuahua Rodeo Criollo, appears to be larger than their Mexican Criollo biotype counterparts, 
like the Mixteco, or other Chihuahua Rodeo types (Table 2 and Figure 5). They appear to be moderately framed compared to smaller Mexican or larger US and South American breeds from drier and wetter environments, respectively (Table 2). We developed a quadratic regression of reported Criollo mature cow weights against average precipitation from each biotype's presumed location of long-term adaptation and found a fairly strong relationship ( $\mathrm{R} 2=0.74)$ between biotype and regional precipitation, a proxy for available vegetation, suggesting that Criollo are presumably well-matched in size to their native grazing environments (Figure 5).

Table 2. List of several Criollo biotypes, and their respective weights $(\mathrm{kg})$ and regional annual precipitation (mm) by various authors, countries, and regions.

\begin{tabular}{|c|c|c|c|c|c|}
\hline $\begin{array}{l}\text { Country of } \\
\text { Origin }\end{array}$ & $\begin{array}{l}\text { Region } \\
\text { of Origin }\end{array}$ & $\begin{array}{c}\text { ppt } \\
(\mathrm{mm})\end{array}$ & Author & Biotype/Breed & $\begin{array}{l}\text { are weight } \\
(\mathrm{kg})\end{array}$ \\
\hline México & $\begin{array}{l}\text { Puebla, Oaxaca } \\
\text { y Guerrero }\end{array}$ & 522 & $\begin{array}{c}\text { Méndez Mendoza et al. } \\
\text { (2002) }\end{array}$ & Mixteco & 194.0 \\
\hline México & $\begin{array}{l}\text { Magdalena Tequi- } \\
\text { sistlan, Oaxaca }\end{array}$ & 321 & Perezgrovas-Garza, (2017) & Mixteco & 224.5 \\
\hline México & Chihuahua & 320 & Hernández Sandoval, (2012) & Chihuahua Rodeo & 238.7 \\
\hline México & La Cofradia, Oaxaca & 655 & Perezgrovas-Garza (2017) & Mixteco & 283.0 \\
\hline Bolivia & Gran Chaco & 700 & Marquardt et al. (2018) & Chaqueño & 328.0 \\
\hline Argentina & $\begin{array}{l}\text { Tucuman Santiago del } \\
\text { Estero y Formosa }\end{array}$ & 997 & Tagle and Inchausti (1946) & Fronterizo & 325.0 \\
\hline Argentina & Leales, Tucuman & 795 & Martínez et al. (2000) & Argentino & 383.0 \\
\hline México & $\begin{array}{l}\text { Copper Canyon, } \\
\text { Chihuahua }\end{array}$ & 923 & This study & Rarámuri (Chihuahua) & 389.7 \\
\hline United States & Texas/ Oklahoma & 762 & Halloran and Shrader (1960) & Texas Longhorn & 399.6 \\
\hline United States & Florida/ Southeast US & 1371 & Sponenberg and Olson (1992) & Florida Cracker & 399.6 \\
\hline Venezuela & $\begin{array}{l}\text { Carrasquero station } \\
\text { INTA }\end{array}$ & 916 & Contreras et al. (2011) & Criollo Limonero & 403.9 \\
\hline Colombia & Misma y Cordoba & 2065 & Ossa et al. (2011) & Costeño con Cuernos & 415.0 \\
\hline Brazil & Sierra de Santa Catalina & 1550 & Camargo (1990) & Brazilian & 415.1 \\
\hline
\end{tabular}

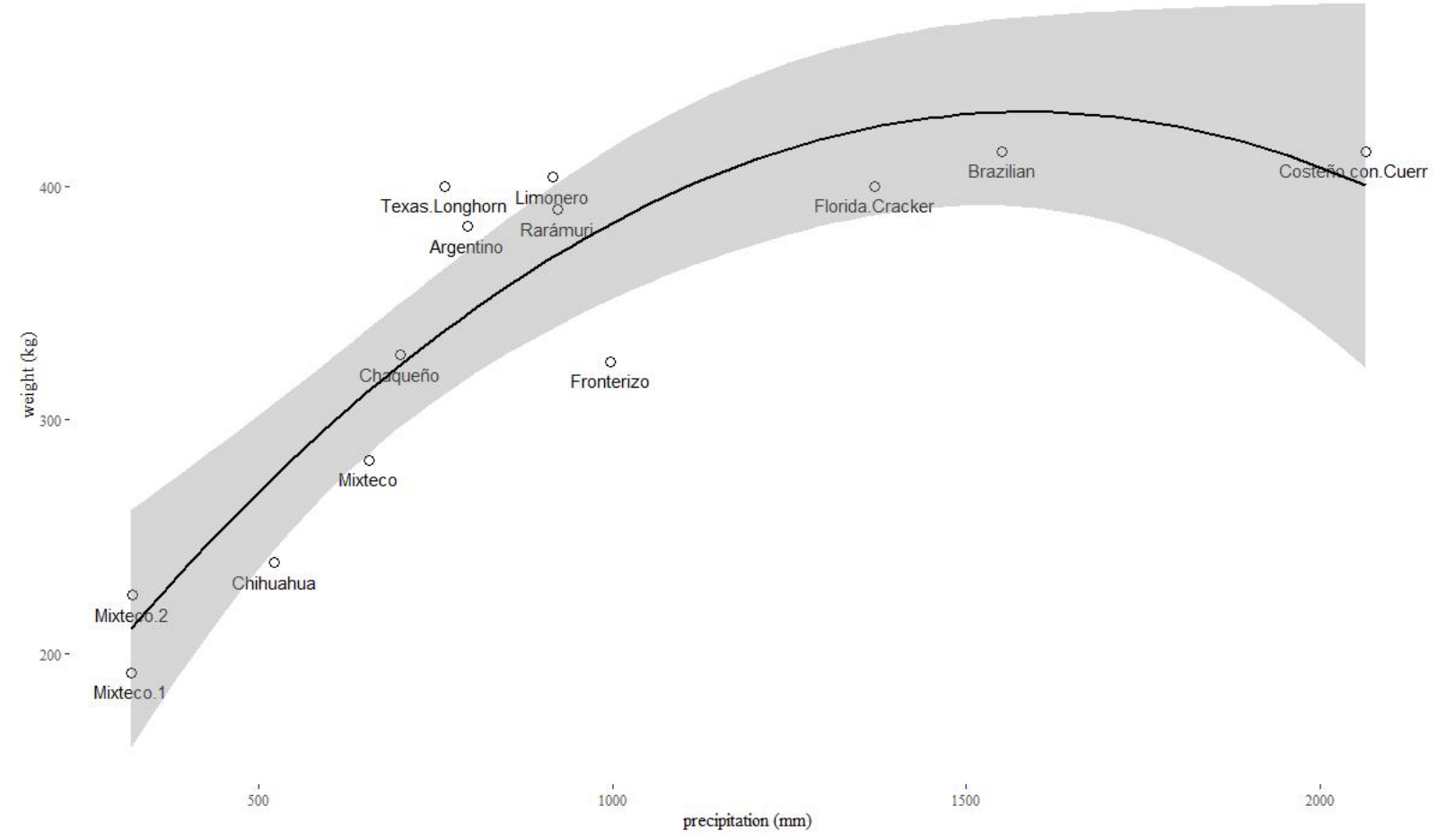

Figure 5. Relationship between various mature Criollo cow biotype weights and annual precipitation of their native habitat. $\mathrm{y}=-0.0001 \mathrm{x}^{2}+$ $0.4005 x+103.03 ; \mathrm{R}^{2}=0.7398$. Gray region shows the $95 \%$ confidence interval. 
Scasta et al. (2016) suggested that the effects of drought and other extreme weather events could be mitigated by "matching the animal to the environment". These authors argued that smaller cows could produce larger calf crop totals than their larger counterparts while utilizing fewer forage resources due to their lower metabolic weights. They also noted that smaller framed cattle breeds of lighter color are more heat-tolerant, tend to forage on shrubs, produce less milk (the greatest energy demand in a cow's life cycle), are often more reproductively efficient, and can be cross-bred to benefit from the hybrid vigor effect (Scasta et al., 2016). Rarámuri Criollo cows show a number of these traits (Nyamuryekung'e 2020) and when crossed with improved beef breed bulls, produce faster-growing heavier steers that can be finished on grass in Chihuahuan Desert pastures (McIntosh, 2018). Raising Rarámuri Criollo cows can be financially advantageous because of fewer veterinary and overhead costs due to their rusticity and because of a greater calf crop (per kilogram) compared to improved beef breeds (Enyinnaya, 2016).

\section{Conclusions}

Rarámuri Criollo cattle introduced from Mexico into the southwestern United States almost two decades ago are a medium-sized Criollo biotype that could be raised for beef production (Spiegal et al., 2020). Though smaller than conventional beef breeds such as Angus, Hereford, or Charolais $(535,502$, and $556 \mathrm{~kg}$, respectively; Urick et al., 1971), or other heritage beef breeds like Scottish Highland and Ankole-Watusi (500 and $460 \mathrm{~kg}$, respectively; TLC, 2020; Long, 2008; Pauler et al., 2019), RC cattle appear to be well- matched to the southwestern US and northern Mexico environments as evidenced by numerous studies that evaluated their grazing behavior (McIntosh, 2018; Nyamuryekung'e et al., 2020; Peinetti et al., 2011; Spiegal et al., 2019), weight gains, and meat quality (McIntosh, 2018). Conservation of this heritage genetic resource could be critically important for climate change adaptation of ranches in the Desert Southwest.

\section{Acknowledgments}

We wish to dedicate this manuscript to and acknowledge our dear mentor, colleague, and friend, Alfredo "Freddy" L. Gonzalez who selflessly dedicated himself to the preservation and study of Rarámuri Criollo cattle. His many words of wisdom about the history, legacy, and morphology of this biotype and anecdotal evidence of their unique behaviors have informed much of our research. We wish also to acknowledge the Tarahumara communities of the Sierra Madre Occidental who have maintained Rarámuri Criollo cattle for over twenty-five generations. Our sincere thanks to Adrienne Dawes for help with data collection, and also to members of the JER who have helped move forward the ongoing efforts of our research group.

\section{Literature Cited}

Allred, B. W., Fuhlendorf, S. D., \& Hamilton, R. G. 2011. The role of herbivores in Great Plains conservation: Comparative ecology of bison and cattle. Ecosphere, 2(3):art26. doi:10.1890/ES1000152.1

Anderson, D. M., Estell, R. E., Gonzalez, A. L., Cibils, A. F., \& Torell, L. A. 2015. Criollo Cattle: Heritage Genetics for Arid Landscapes. Rangelands, 37: 62-67. https://doi.org/10.1016/j.rala.2015.01.006

Camargo, A. H. A. 1990. Ganado criollo del Brasil: Origen y características zootécnicas. Animal Genetic Resources/Ressources génétiques animales/Recursos genéticos animales, 7: 11-18.

Contreras, G., Chirinos, Z., Zambrano, S., Molero, E., \& Paéz, A. 2011. Caracterización morfológica e índices zoométricos de vacas Criollo Limonero de Venezuela. Revista de la Facultad de Agronomía de La Universidad del Zulia, 28: 91-103. https://produccioncientificaluz.org/index.php/agro nomia/article/view/26867/27493
Enyinnaya, J. C. 2016. A case study of the economics of the economics of Criollo cattle production in the deserts of southern New Mexico. New Mexico State University.

FAO. 2007. The state of the world's commission on genetic resources for food and agriculture. (B. Rischkowsky \& D. Pilling, Eds.)Food and Agriculture Organization of the United Nations. Rome.

Ginja, C., Gama, L. T., Cortés, O., Burriel, I. M., Vegapla, J. L., Penedo, C., Sponenberg, P., Cañón, J., Sanz, A., Alves, A., Alvarez, L. A., Giovambattista, G., \& Agha, S. 2019. The genetic ancestry of American Creole cattle inferred from uniparental and autosomal genetic markers, 1-16.

Halloran, A. F., \& Shrader, C. A. 1960. Longhorn Cattle Management on Wichita Mountains Wildlife Refuge. The Journal of Wildlife Management, 24: 191.

Havstad, K. M., Brown, J. R., Estell, R., Elias, E., Rango, A., \& Steele, C. 2018. Vulnerabilities of Southwestern U.S. Rangeland-based animal 
agriculture to climate change. Climatic Change, 148: 371-386.

Hawkes, J. M., Lillywhite, J. M., \& Libbin, J. D. 2006. A sporting alternative. Rangelands, 28: 15-17.

Hernández Sandoval, R. 2012. Tipificacion del ganado Criollo Mexicano de los Estados de Chihuahua, Baja California, Guerrero, Oaxaca, Puebla y Nayarit. Asociacion de Criadores de Ganado Criollo Mexicano, A.C., 1-119.

Huson, H. J., Kim, E. S., Godfrey, R. W., Olson, T. A., McClure, M. C., Chase, C. C., Rizzi, R., O’Brien, A. M. P., Van Tassell, C. P., Garcia, J. F., \& Sonstegard, T. S. 2014. Genome-wide association study and ancestral origins of the slick-hair coat in tropically adapted cattle. Frontiers in Genetics, 5: 1-12.

Long, J. A. 2008. Reproductive Biotechnology and Gene Mapping : Tools for Conserving Rare Breeds of Livestock, 43: 83-88.

Marquardt, S., Soto, D., \& Joaquin, N. 2018. Foraging Behavior of Criollo vs. Brahman $\times$ Criollo Crossbreds in the Bolivian Chaco: Case Study. Rangeland Ecology \& Management, 71: 757-761.

Martínez, R. D., Fernández, E. N., Género, E. R., \& Rumiano, F. J. L. 2000. El ganado bovino criollo en argentina. Archivos de Zootecnia, 49: 353-361.

McIntosh, M. M. 2018. Weight gain and behavior of criollo vs crossbred steers developed on chihuahuan desert rangeland. New Mexico State University.

Méndez Mendoza, M., Serrano Palapa, J., Avila Benítez, R., Rosas García, M., \& Méndez Palacios, N. 2002. Caracterización morfométrica del bovino Criollo Mixteco. Archivos de zootecnia, 51: 217-221.

NACA. 2010. North American Corriente Association Judging Guidelines for Corriente Cows. North American Corriente Association.

NACA. 2020. North American Corriente Association: Unique Traits.

NRCS, N. R. C. S. 2017. Soil survey, Dona Ana County, New Mexico. USDA - Natural Resources Conservation Service.

Nyamuryekung'e, S. 2020. Foraging Habits, Heat Tolerance, and Maternal Behavior of Heritage Vs. Improved Beef Cattle Grazing Desert Rangeland. New Mexico State University.

Nyamuryekung'e, S., Cibils, A. F., Estell, R. E., McIntosh, M. M., Vanleeuwen, D. M., Steele, C., Gonzalez, A. L., Spiegal, S. A., Reyes, L. A., \& Rodriguez Almeida, F. (n.d.). Foraging behavior and body temperature of heritage vs. commercial beef cows in relation desert ambient heat. Journal of Arid Environments.
Nyamuryekung'e, S., Cibils, A. F., Estell, R. E., VanLeeuwen, D., Steele, C., Estrada, O. R., Almeida, F. A. R., González, A. L., \& Spiegal, S. 2020. Do Young Calves Influence Movement Patterns of Nursing Raramuri Criollo Cows on Rangeland? Rangeland Ecology and Management, 73: 84-92.

Ossa, G., Abuabara, Y., Pérez García, J. E., \& Martínez, G. 2011. El ganado criollo colombiano Costeño con Cuernos (CCC). Animal Genetic Resources/Ressources génétiques animales/Recursos genéticos animales, 48: 101-107.

Pauler, C. M., Isselstein, J., Braunbeck, T., \& Schneider, M. K. 2019. Influence of Highland and productionoriented cattle breeds on pasture vegetation: A pairwise assessment across broad environmental gradients. Agriculture, Ecosystems and Environment, 284: 106585.

Peinetti, H. R., Fredrickson, E. L., Peters, D. P. C., Cibils, A. F., Roacho-Estrada, J. O., \& Laliberte, A. S. 2011. Foraging behavior of heritage versus recently introduced herbivores on desert landscapes of the American Southwest. Ecosphere, 2: 1-14.

Perezgrovas-Garza, R. 2017. Catálogo ilustrado de los bovinos criollos de México: razas locales y sistemas empíricos de manejo. Universidad Autónoma de Chiapas, Instituto de Estudios Indígenas-UNACH.

Pitt, D., Bruford, M. W., Martínez, R., Sevane, N., \& Orozco-terwengel, M. B. P. 2019. Demography and rapid local adaptation shape Creole cattle genome diversity in the tropics, 105-122.

Polley, H. W., Briske, D. D., Morgan, J. A., Wolter, K., Bailey, D. W., \& Brown, J. R. 2013. Climate change and North American rangelands: Trends, projections, and implications. Rangeland Ecology and Management, 66: 493-511.

Rook, A. J., Dumont, B., Isselstein, J., Osoro, K., WallisDeVries, M. F., Parente, G., \& Mills, J. 2004. Matching type of livestock to desired biodiversity outcomes in pastures - A review. Biological Conservation, 119: 137-150.

Russell, N. D., Rios, J., Erosa, G., Remmenga, M. D., \& Hawkins, D. E. 2000. Genetic differentiation among geographically isolated populations of Criollo cattle and their divergence from other Bos taurus breeds. Journal of Animal Science, 78: 2314-2322.

Scasta, J. D., Lalman, D. L., \& Henderson, L. 2016. Drought Mitigation for Grazing Operations: Matching the Animal to the Environment. Rangelands, 38: 204-210.

Spiegal, S., Cibils, A. F., Bestelmeyer, B. T., Steiner, J. L., Estell, R. E., Archer, D. W., Auvermann, B. W., Bestelmeyer, S. V., Boucheron, L. E., Cao, H., Cox, A. R., Devlin, D., Duff, G. C., Ehlers, K. K., Elias, E. H., 
Gifford, C. A., Gonzalez, A. L., Holland, J. P., Jennings, J. S., Marshall, A. M., McCracken, D. I., McIntosh, M. M., Miller, R., Musumba, M., Paulin, R., Place, S. E., Redd, M., Rotz, C. A., Tolle, C., \& Waterhouse, A. 2020. Beef Production in the Southwestern United States: Strategies Toward Sustainability. Frontiers in Sustainable Food Systems, 4.

Spiegal, S., Estell, R. E., Cibils, A. F., James, D. K., Peinetti, H. R., Browning, D. M., Romig, K. B., Gonzalez, A. L., Lyons, A. J., \& Bestelmeyer, B. T. 2019. Seasonal Divergence of Landscape Use by Heritage and Conventional Cattle on Desert Rangeland. Rangeland Ecology and Management, 72: 590-601.

Sponenberg, D.P., Olson, T. A. 1992. Colonial Spanish Cattle in the USA: History and Present Status. Archivos de Zootecnia, 41: 401-414.

Sponenberg, D. P., Martin, A., Couch, C., \& Beranger, J. 2019. Conservation strategies for local breed biodiversity. Diversity, 11.
Tagle, Ezequiel, C., \& Inchausti, D. 1946. Raza Criollo. In: CAP Razas Productoras de Carne. El Ateneo: pp. $370-385$.

[TLC], T. L. C. 2020. The Livestock Conservancy: Ankole-Watusi Cattle. The Livestock Conservancy: Cattle.

Ulloa-Arvizu, R., Gayosso-Vázquez, A., Ramos-Kuri, M., Estrada, F. J., Montaño, M., \& Alonso, R. A. 2008. Genetic analysis of Mexican Criollo cattle populations. Journal of Animal Breeding and Genetics, 125: 351-359.

Urick, J. J., Knapp, B. W., Brinks, J. S., Pahnish, O. F., \& Riley, T. M. 1971. Relatioships Between Cow Weights and Calf Weaning Weights in Angus, Charolais, and Hereford breeds. Journal of Animal Science, 33(2): 343-348, https://doi.org/10.2527/jas1971.332343x. 